Participatory Educational Research (PER)

Special Issue 2016-I, pp., 57-62; 01 January, 2016

Available online at http://www.partedres.com

ISSN: 2148-6123

http://dx.doi.org/10.17275/per.16.spi.1.7

\title{
The Use of Language Learning Strategies in Course Books
}

\author{
Vildan ÖZDEMİ*, \\ Educational Faculty, Mersin University, Mersin, Turkey \\ Mehmet Burçin ÖZKAN \\ Ministry of Education, Mersin, Turkey
}

\begin{abstract}
Language Learning Strategies (LLS) are some kind of techniques that help students with learning a second or foreign language. Green and Oxford (1995) defines language learning strategies as specific actions or techniques that students use, often intentionally, to improve their progress in developing second language skills. LLS became the subject matter in the field of language learning in 1970s, and it has been understood that Language Learning Strategies have a crucial role in the language learning and teaching process. Course books are one of the most important teaching materials in language classrooms and they play an important role to apply language learning strategies to the classroom activities. This study aims to investigate the use of language learning strategies in the English language course books in Turkey. 2nd to 8th grade course books have been chosen from state schools and language learning strategies used in the course books have been defined according to Chamot and O'Malley's language learning strategy classifications. The study is intended to provide answers to the following questions: Which language learning strategies are used in the English language course books in primary and secondary schools? Are there any differences between the language course books as for the strategy use.
\end{abstract}

Key Words: Language Learning Strategies - Young Learners - EFL

Teaching/Learning- Course books

\section{Introduction}

Language Learning Strategies (LLS) are some kind of techniques that help students with learning a second or foreign language. Green and Oxford (1995) defines language learning strategies as specific actions or techniques that students use, often intentionally, to improve their progress in developing second language skills. Language learning strategies became the subject matter in the field of language learning in 1970s, and it has been understood that Language Learning Strategies have a crucial role in the language learning and teaching process. As Oxford (1986) states LLS improve language performance, encourage learner autonomy, and expand the role of the teacher in useful ways. Also, Rubin (1975) indicated that if instructors knew successful language learners' strategies, they could help less successful learners. As European countries studies about LLS have gained popularity in 
recent years in Turkey. For example, In Turkey, Hismanoglu (2000) investigated the ideas of different researchers about Language Learning Strategies and he evaluated all the classifications based on the variables such as gender, and class. Also, Alptekin (2007) investigated whether there were differences while choosing a Language Learning Strategy and what was the frequency of the strategies while learning two foreign languages in a formal and an informal language learning environment.

There have been many classifications by various field researchers depending on variables. For example, Oxford (1986) divides LLS into two groups; Direct and Indirect Strategies. Also, O'Malley and Chamot (1990) classifies LLS as Metacognitive Strategies, Cognitive Strategies, and Social and Affective Strategies. Classroom materials form an important part of language learning and teaching process. Course books are one of the most important teaching materials in language classrooms. According to McGrath (2006) course books are key element in language teaching and learning and also states that " course books will tend to dictate what is taught, in what order and, to some extent, how as well as what learners learn." Also course books play an important role to apply language learning strategies to the classroom activities. LLS are used in the course books explicitly or implicitly.

This study aims to investigate the use of language learning strategies in the English language course books in Turkey. 2nd to 8th grade course books have been chosen from state schools and language learning strategies used in the course books have been defined according to Chamot and O'Malley's language learning strategy classifications.

The study is intended to provide answers to the following questions: Which language learning strategies are used in the English language course books in primary and secondary schools? Are there any differences between the language course books as for the strategy use?

\section{Methodology}

In this study, English language course books used in the 2015-2016 academic year in public schools in Turkey have been chosen to determine their language learning strategy. Instructions in the units have been examined according to O'Malley and Chamot's LLS classifications.

Table 1. LLS Classification of O'Malley and Chamot

\begin{tabular}{lll}
\hline Metacognitive Strategies & Cognitive Strategies & $\begin{array}{c}\text { Social and Affective } \\
\text { Strategies }\end{array}$ \\
\hline Planning & Repetition & Questioning for \\
Advance Organization & Resourcing & Cooperation \\
& Grouping & Self-talk \\
Organizational Planning & Note Taking & Self- \\
Directed Attention & Deduction/Induction & reinforcement \\
Selective Attention & Substitttion & \\
Self-management & Elaboration & \\
Self-monitoring & Personal & \\
& Elaboration & \\
Comprehension Monitoring & World Elaboration & \\
Production Monitoring & Academic & \\
Auditory Monitoring & Elaboration & \\
& Between Parts & \\
Visual Monitoring & Elaboration & \\
Style Monitoring & Questioning & \\
Strategy Monitoring & Elaboration & \\
Plan Monitoring & Self-evaluative & \\
Double-check Monitoring & Elaboration & \\
Problem Identification & Creative & \\
\hline
\end{tabular}




\begin{tabular}{ll}
\hline Self-evaluation & Elaboration \\
Production Evaluation & Imagery \\
Performance Evaluation & Summerization \\
Ability Evaluation & Translation \\
Strategy Evaluation & Transfer \\
Language & Inference \\
Evaluation & \\
\hline
\end{tabular}

Turkish education system 2, 3. and 4 classes are primary school classes and 5, 6, 7. and 8 . classes are secondary school classes. 2 to 6 grade curriculum was designed according to A1 descriptors also 7 and 8 grade curriculum was designed according to A2 descriptors .

Table 2. LLS Strategies in 2nd Class Course Book

\begin{tabular}{|c|c|c|}
\hline & f & $\%$ \\
\hline \multicolumn{3}{|c|}{ 1) Metacognitive Strategies } \\
\hline Selective Attention & 12 & 7.9 \\
\hline Production Evaluation & 12 & 7.9 \\
\hline \multicolumn{3}{|c|}{ 2) Cognitive Strategies } \\
\hline Repetition & 35 & 23 \\
\hline Grouping & 9 & 5,9 \\
\hline Personal Elaboration & 17 & 11.1 \\
\hline World Elaboration & 7 & 4,6 \\
\hline Imagery & 51 & 33.5 \\
\hline \multicolumn{3}{|c|}{ 3) Social And Affective strategies } \\
\hline Cooperation & 9 & 5,9 \\
\hline
\end{tabular}

As presented in Table 2 percentage of Metacognitive Strategy use is 15.8 and percentage of Cognitive Strategy use is 78.1 and also percentage of Social and Affective Strategy use is 5.9 in second class course book. According to this result Cognitive Strategies are mostly used in second class course book.

Table 3. LLS Strategies in 3rd Class Course Book

\begin{tabular}{lcc}
\hline \multicolumn{1}{c}{ 1) Metacognitive Strategies } & $\mathbf{f}$ & \% \\
\hline Selective Attention & 77 & 23.1 \\
Production Evaluation & 43 & 12.9 \\
Language Repertoire Evaluation & 3 & 0.9 \\
& & \\
2) Cognitive Strategies & 22 & 6.6 \\
\hline Repetition & 14 & 4.2 \\
\hline Personing Elaboration & 24 & 7.2 \\
\hline World Elaboration & 7 & 2.1 \\
\hline Imagery & 121 & 36.4 \\
\hline 3) Social And Affective strategies & 21 & 6.3 \\
\hline Cooperation & & \\
\hline
\end{tabular}

As presented in Table 3 percentage of Metacognitive Strategy use is 36.9 and percentage of Cognitive Strategy use is 56.5 and also percentage of Social and Affective Strategy use is 6.3 in third class course book. According to this result Cognitive Strategies are mostly used in third class course book. 
Table 4. LLS Strategies in 4th Class Course Book

1) Metacognitive Strategies

$\begin{array}{lll}\text { Selective Attention } & 37 & 15\end{array}$

Production Evaluation $\quad 40 \quad 15.1$

2) Cognitive Strategies

\begin{tabular}{lcc} 
Repetition & 24 & 9 \\
\hline Grouping & 21 & 7.9 \\
\hline Note Taking & 16 & 6 \\
\hline Personal Elaboration & 11 & 4.1 \\
\hline World Elaboration & 20 & 7.5 \\
\hline Imagery & 67 & 25.3 \\
\hline Inference & 5 & 1.9 \\
\hline \multicolumn{1}{c}{ 3) Social And Affective strategies } & & 8.7 \\
\hline Cooperation & 23 & \\
\hline
\end{tabular}

As presented in Table 4 percentage of Metacognitive Strategy use is 30.1 and percentage of Cognitive Strategy use is 61.7 and also percentage of Social and Affective Strategy use is 8.7 in fourth class course book. According to this result Cognitive Strategies are mostly used in fourth class course book.

Table 5. LLS Strategies in 5th Class Course Book

\begin{tabular}{lcc}
\hline & f & \% \\
\hline 1) Metacognitive Strategies & & \\
\hline Advance Organization & 5 & 1.6 \\
& & \\
Selective Attention & 35 & 11.5 \\
Production Evaluation & 101 & 33.4 \\
& & \\
2) Cognitive Strategies & & \\
Resourcing & 2 & 0.6 \\
\hline Repetition & 3 & 1 \\
\hline Grouping & 12 & 4 \\
\hline Note Taking & 15 & 4.9 \\
\hline Personal Elaboration & 19 & 6.2 \\
\hline World Elaboration & 10 & 3,3 \\
\hline Imagery & 45 & 14.9 \\
\hline Inference & 15 & 4.9 \\
\hline 3) Social And Affective strategies & & \\
\hline Cooperation & 40 & 13.2 \\
\hline
\end{tabular}

As presented in Table 5 percentage of Metacognitive Strategy use is 46.5 and percentage of Cognitive Strategy use is 39.8 and also percentage of Social and Affective Strategy use is 13.2 in fifth class course book. According to this result Metacognitive Strategies are mostly used in fifth class course book.

Table 6. LLS Strategies in 6th Class Course Book

\begin{tabular}{lcc} 
& f & \% \\
\hline 1) Metacognitive Strategies & & 3.6 \\
\hline Advance Organization & 11 & \\
& & 15.3 \\
Selective Attention & 46 & 26.7 \\
Production Evaluation & 80 & 0.3
\end{tabular}


2) Cognitive Strategies

\begin{tabular}{lcc} 
Resourcing & 1 & 0.3 \\
\hline Repetition & 3 & 1 \\
\hline Grouping & 6 & 2 \\
\hline Note Taking & 21 & 7 \\
\hline Personal Elaboration & 17 & 5.7 \\
\hline World Elaboration & 12 & 4 \\
\hline Imagery & 37 & 12.3 \\
\hline Inference & 17 & 5.7 \\
\hline 3) Social And Affective strategies & & \\
\hline Cooperation & 47 & 15.7 \\
\hline
\end{tabular}

As presented in Table 6 percentage of Metacognitive Strategy use is 45.9 and percentage of Cognitive Strategy use is 38 and also percentage of Social and Affective Strategy use is 15.7 in sixth class course book. According to this result Metacognitive Strategies are mostly used in sixth class course book.

Table 7. LLS Strategies in 7th Class Course Book

\begin{tabular}{lcc}
\hline \multicolumn{1}{c}{ 1) Metacognitive Strategies } & f & \% \\
\hline Advance Organization & 10 & 2.5 \\
\hline $\begin{array}{l}\text { Organizational Planning } \\
\text { Selective Attention }\end{array}$ & 14 & 3.6 \\
& 68 & 17.6 \\
Production Evaluation & 115 & 29.8 \\
Language Repertoire Evaluation & 23 & 5.9 \\
2) Cognitive Strategies & & \\
Resourcing & 4 & 1 \\
\hline Repetition & 1 & 0.2 \\
\hline Grouping & 15 & 3.9 \\
\hline Note Taking & 13 & 3.3 \\
\hline Personal Elaboration & 12 & 3.1 \\
\hline World Elaboration & 17 & 4.4 \\
\hline Imagery & 44 & 11.4 \\
\hline Inference & 24 & 6.2 \\
\hline 3) Social And Affective strategies & & \\
\hline Cooperation & 25 & 6.4 \\
\hline
\end{tabular}

As presented in Table 7 percentage of Metacognitive Strategy use is 59.4 and percentage of Cognitive Strategy use is 33.5 and also percentage of Social and Affective Strategy use is 6.4 in seventh class course book. According to this result Metacognitive Strategies are mostly used in seventh class course book.

Table 8. LLS Strategies in 8th Class Course Book

\begin{tabular}{lcc}
\hline & $\mathbf{f}$ & $\mathbf{\%}$ \\
\hline 1) Metacognitive Strategies & & \\
\hline Advance Organization & 29 & 6,7 \\
\hline Organizational Planning & 19 & 4,4 \\
Selective Attention & 57 & 13,1 \\
Production Evaluation & 81 & 18,7 \\
Language Repertoire Evaluation & 2 & 0,4 \\
2) Cognitive Strategies & & \\
Resourcing & 10 & 2,3 \\
\hline Repetition & 9 & 2,3 \\
\hline Grouping & 10 & 6,9 \\
\hline Note Taking & 30 & 0,7 \\
\hline Substitution & 3 & 7,8 \\
\hline Personal Elaboration & 34 & \\
\hline
\end{tabular}




\begin{tabular}{lcc}
\hline World Elaboration & 15 & 3,4 \\
\hline Imagery & 24 & 5,5 \\
\hline Inference & 25 & 5,7 \\
\hline 3) Social And Affective strategies & & \\
\hline Cooperation & 84 & 19,4 \\
\hline
\end{tabular}

As presented in Table 8 percentage of Metacognitive Strategy use is 43.3 and percentage of Cognitive Strategy use is 36.4 and also percentage of Social and Affective Strategy use is 19.4 in eighth class course book. According to this result Metacognitive Strategies are mostly used in eighth class course book.

\section{Discussion and Conclusion}

The main objective of this study is to find out the LLS use of language learning strategies in the English language course books. The results of the findings show that in primary school course books Cognitive Strategies are mostly used; however, in secondary school course books Metacognitive Strategies are mostly used; moreover, both primary and secondary school course books Social and Affective Strategies are used least.

In the light of the results, it can be said that in the course books strategy diversity increased when grade level increase for example, in second class course books eight different strategies are used; however, in the eight grade course books fifteen different strategies are used.

The above tables indicate that publishers have an impact on strategy use in course books for example, sixth and eight class course books are published by the same publisher and Personal Elaboration Strategy is used more than World Elaboration Strategy but seventh grade course book is published by different publisher and World Elaboration Strategy is used more than Personal Elaboration Strategy.

\section{References}

Alptekin, C. (2007). Foreign language learning strategy choice: naturalistic versus instructed language acquisition. Journal of Theory and Practice in Education, $3(1), 4-11$

Arda, A., \& Onay, Ö. (2015). Sunshine 4. Lider Yayınc1lık.

Arda, A., \& Onay, Ö. (2015). Sunshine 7. Lider Yayınc1l1k.

Dağlığlu, Ö. (2015). Ingilizce 3. Bilen Yayıncılık.

Green, M. J. \& Oxford, R. (1995). A closer look at learning strategies, L2 proficiency, and gender. Tesol Quarterly Vol.29, No.2

Hismanoglu, M. (2000). Language learning strategies in foreign language learning and teaching. The Internet TESL Journal, Vol. VI, No. 8

Komisyon, M.E.B. (2015). I Know English 2. Ankara: Saray Maatbacılık.

McGrath, I. (2006). Teachers' and learners' images for coursebooks. ELT Journal, 60(2), 171180.

O'Malley, J. M., \& Chamot, A. U. (1990). Learning strategies in second language acquisition. Cambridge University Press.

Oxford, R. L.(1986). second language learning strategies: current research and implication for practice. ERIC Document Reproduction Service No. ED 278273.

Rubin, J. (1975). What the "good language learner" can teach us. Tesol Quarterly, 9, $41-51$.

Şener, M. (2015). Upturn English 8. Evrensel İletişim Yayınları.

Şilit, G. (2015). English Net 5. Evrensel İletişim Yayınları.

Şilit, G. (2015). English Net 6. Evrensel İletişim Yayınları. 